\title{
Hak Prerogatif Presiden dalam Perspektif Hukum Tata Negara Indonesia
}

\author{
Ni'matul Huda
}

\begin{abstract}
The prerogatives of the president of our country have been limitated significantly since the General Assembly (MPR) has amended the constitution. Many its articles which had empowered the president to rule the state authoritatively have been corrected by the amendment as the president should get approval from parliament (DPR) is some certain cases or consideration from the Representative Body of Supreme Court in the other ones. In order to control President's power the parliament would be obliged to exploit its rights extensively and proportionally. However, it would be very important to declare his power on the constitution or codes with clear.
\end{abstract}

\section{Pendahuluan}

Ketika Presiden Abdurrahman Wahid berkuasa, perbincangan seputar hak prerogatif muncul ke permukaan. Hal ini berkaitan dengan tindakan Presiden yang sering memecat dan mengangkat menterimenterinya atau pejabat lain, misalnya Kapolri, tanpa ada alasan dan kriteria yang jelas, sehingga menimbulkan berbagai reaksi dalam masyarakat, baik yang pro ataupun yang kontra. Ketika itu, Presiden Abdurrahman Wahid memecat Yusuf Kalla dari jabatan Menteri Perindustrian dan Perdagangan, dan Laksamana Sukardi dari jabatan Menteri Negara Penanaman Modal dan Pembinaan BUMN (masing-masing dari Golkar dan PDI Perjuangan).

Sebagian kalangan ada yang beranggapan bahwa tindakan Presiden tersebut masih dalam koridor konstitusi, karena dipandang

sebagai bagian dari hak prerogatif Presiden. Sebagian kalangan lain berpandangan berbeda, bahwa tindakan Presiden bukan dalam kerangka hak prerogatif Presiden, tetapi justru pelanggaran atau kesewenangwenangan.

Kasus seperti ini bukan yang pertama kali terjadi, ketika pemerintahan dipegang oleh $\mathrm{H}$. M. Soeharto kasus serupa sering pula terjadi. Misalnya, pemberhentian Harmoko sebagai Menteri Penerangan dan digantikan R. Hartono, kemudian Harmoko diangkat sebagai Menteri Urusan Khusus. Anggota DPR/MPR kala itu, ada yang mengusulkan supaya dalam pengangkatan dan pemberhentian menteri, Presiden mengkonsultasikannya dengan DPR, tetapi usulan itu tidak pernah ditanggapi oleh Presiden Soeharto. Begitu pula halnya ketika Presiden Abdurrahman Wahid 
berkuasa, usulan yang sama juga muncul, tetapi Presiden Abdurrahman Wahid tidak menghiraukannya, karena hal ini dipandang sebagai hak prerogatifnya.

Sebagai akibat dari pemberhentian dua orang menteri tersebut, Yusuf Kalla dan Laksamana Sukardi, oleh Presiden Abdurrahman Wahid, sebagian anggota DPR khususnya dari kalangan Fraksi GOLKAR dan PDI Perjuangan bereaksi keras mempertanyakan alasan pemberhentian. Pada akhirnya kasus tersebut berujung pada pengajuan "hak meminta keterangan pada Presiden" - sering disebut sebagai hak interpelasi- berlangsung di DPR 20 Juli 2000.

Begitu pula dalam kasus pemberhentian dan pengangkatan Kapolri. Hal ini pun ada yang berpandangan bahwa tindakan Presiden tidak melanggar konstitusi, karena masih dalam batas kekuasaan Presiden sebagai panglima tertinggi dari semua angkatan sebagaimana yang diamanatkan oleh Pasal 10 UUD 1945. Dengan kata lain, pengangkatan dan pemberhentian Kapolri adalah hak prerogatif Presiden. Tetapi, ketika Adnan Buyung Nasution dkk. mengajukan permohonan keberatan atas keputusan yang dikeluarkan Presiden Abdurrahman Wahid melalui Hak Uji Materiil (HUM) ke Mahkamah Agung, ternyata putusan Mahkamah Agung menerima keberatan atas permohonan hak uji materiil yang diajukan Buyung Nasution tersebut. Artinya, secara yuridis Keputusan Presiden dalam mengangkat dan memberhentikan Kapolri tanpa melalui persetujuan DPR dipandang bertentangan dengan peraturan yang lebih tinggi, yaitu TAP MPR No. VII/MPR/2000.'

Sebagian ahli hukum tata negara berpandangan bahwa UUD 1945 memberikan hak prerogatif pada Presiden, sebagaimana yang selama ini dipahami masyarakat, diatur di dalam UUD 1945 Pasal 10 sampai dengan Pasal 15 dan 17. Sebagian ahli yang lain mengatakan bahwa UUD 1945 tidak mengenal hak prerogatif, karena semua sudah tertuang di dalam UUD 1945 dan peraturan perundangundangan lainnya. Pertanyaan yang muncul, apakah UUD 1945 memberikan jaminan hak prerogatif pada presiden? Apakah hak prerogatif Presiden masih ada ketika UUD 1945 telah mengalami perubahan sampai tiga kali?

\section{Hak Prerogatif}

Prerogatif secara kebahasaan berasal dari bahasa Latin praerogativa (dipilih sebagai yang paling dahulu memberi suara), praerogrativus (diminta sebagai yang pertama memberikan suara), praerogare (diminta sebelum meminta yang lain). ${ }^{2}$

Sebagai pranata hukum (hukum tata negara), prerogatif berasal dari sistem ketatanegaraan Inggris. Hingga saat ini, pranata prerogatif tetap merupakan salah satu sumber hukum, khususnya sumber hukum tata negara di Kerajaan Inggris. Tidak mudah merumuskan pengertian kekuasaan prerogatif, baik karena sumber historisnya

'Lihat Putusan Mahkamah Agung No. 08 P/HUM/2001 tentang Putusan Menerima Keberatan atas Permohonan Hak Uji Materiil yang dimajukan oleh Tim Pembela Konstitusi 31 Juli 2001.

Bagir Manan. "UUD1945 Tak Mengenal Hak Prerogatif." Harian Republika. Sabtu. 27 Mei 2000. Hlm.. 8. 
sebagai pranata hukum maupun lingkupnya. Pada saat ini, kekuasaan prerogatif makin banyak dibatasi, baik karena diatur oleh undang-undang atau pembatasanpembatasan cara melaksanakannya.

Sejumlah kalangan memandang hak prerogatif merupakan sisa-sisa peninggalan masa otoritarianisme sebelum era pencerahan di Eropa. Pada 15 Juni $1215 \mathrm{kala}$ Raja John bertahta, angin perubahan berembus saat Magna Charta diratifikasi. Piagam tersebut memuat hak-hak istimewa para bangsawan tinggi. Piagam itu dianggap sebagai tonggak yang mengawali upaya pengikutsertaan rakyat dalam manajemen kekuasaan. Setelah Piagam tersebut dirilis, perlahan tapi pasti, kekuasaan raja atau ratu Inggris semakin mengecil. . Semua pemangkasan itu dicantumkan dalam undang-undang. Hak prerogatif adalah kekuasaan yang masih tersisa di tangan raja atau ratu dan tidak diatur undang-undang. Kini, praktis raja atau ratu Inggris hanya menjadi simbol. Dalam praktek ketatanegaraan perannya nyaris nihil. Bentuk hak prerogatif yang sekarang masih dimanfaatkan raja atau ratu, misalnya menganugerahkan gelar kebangsawanan kepada seseorang. ${ }^{3}$

Teori prerogatif yang mutlak dalam eksekutif telah ditolak oleh Mahkamah Agung Amerika Serikat. Dengan demikian, menurut sistem konstitusi Amerika, eksekutif hanya mempunyai kekuasaan-kekuasaan baik yang dengan tegas dinyatakan oleh UUD atau UU, ataupun dengan cara menarik kesimpulankesimpulan tertentu dari UUD atau UU. Oleh karena itu, dalam suatu perkara yang terkenal, Youngstown Sheet \& Tube Co. v Sawyer. Mahkamah Agung Amerika Serikat menolak perintah penyitaan Presiden Truman, dimana Presiden- itu memerintahkan Menteri Perdagangan untuk mengambil alih industri baja guna menghindarkan ancaman pemogokan di pabrik-pabrik baja dan untuk menjamin kelangsungan persediaan baja yang sangat dibutuhkan untuk pertahanan nasional. Mahkamah itu berpendapat bahwa kekuasaan prerogatif untuk menyita industri baja adalah tidak termasuk kekuasaan konstitusional Presiden. ${ }^{4}$

Menurut konstitusi Inggris dan Canada, eksekutif masih mempunyai beberapa discretionary power, yang terkenal sebagai prerogatif raja. Istilah terakhir ini dipergunakan untuk mencakup sekumpulan besar hak-hak dan privilleges yang dipunyai oleh raja dan dilaksanakan tanpa suatu kekuasaan perundang-undangan yang langsung. Di samping itu, jika parlemen menghendaki. dengan undang-undang ia dapat membatalkan prerogatif itu. Dengan kata lain. prerogatif itu ada selama dan sejauh diakui dan diijinkan oleh undang-undang. ${ }^{5}$

Dalam sistem Perancis, kekuasaan perundang-undangan yang diserahkan oleh UUD baru kepada Parlemen telah ditentukan secara limitatif dalam sebuah daftar. Semua soal yang tidak termasuk dalam daftar tindakan-

${ }^{3}$ Forum Keadilan. No. 19. 12 Agustus 2001. HIm.. 14.

"Ismail Suny. 1986. Pergeseran Kekuasaan Eksekutif. Jakarta: Aksara Baru. Him..61.

$5 /$ bid. 
tindakan legislatif yang ditentukan itu, menjadi hak eksekutif untuk mengaturnya. Jadi, kekuasaan eksekutif Perancis telah menarik residuary authority atau kekuasaan yang selebihnya ke bawah kekuasaan konstitusionalnya, tidak hanya "untuk menjamin pelaksanaan undang-undang" seperti ditetapkan oleh UUD yang lalu, tetapi-sejauh mengenai pembagian kekuasaan antara eksekutif dan legislatif, prinsip yang dianut ialah bahwa wewenang umum adalah pada eksekutif untuk mengatur dengan dekrit segala sesuatu yang tidak dengan pengecualian telah diserahkan kepada wewenang badan legislatif. $^{6}$

Dicey merumuskan prerogatif sebagai residu dari kekuasaan diskresi ratu/raja, yang secara hukum tetap dibiarkan dan dijalankan sendiri oleh ratu/raja dan para menteri. Yang disebut dengan kekuasaan diskresi (discretionary power) adalah segala tindakan raja/ratu atau pejabat kenegaraan lainnya yang secara hukum dibenarkan, walaupun tidak ditentukan atau didasarkan. pada suatu ketentuan undang-undang.

Disebut sebagai residu, karena kekuasaan ini tidak lain dari sisa seluruh kekuasaan yang semua ada pada ratu/raja (kekuasaan mutlak) yang kemudian makin berkurang, karena beralih ke tangan rakyat (parlemen) atau unsurunsur pemerintah lainnya, seperti menteri. Kekuasaan prerogatif bersumber pada common law, yaitu hukum tidak tertulis yang berasal dari putusan hakim. Karena, tidak memerlukan suatu dasar undang-undang, oleh sebagian orang kekuasaan prerogatif dipandang sebagai undemocratic and potentially dangerous. $^{7}$

Untuk mengurangi sifat tidak demokratik dan bahaya-bahaya tersebut, maka penggunaan kekuasaan prerogatif dibatasi dengan dialihkan ke dalam undang-undang, kemungkinan diuji melalui peradilan (judicial review), atau kalau akan dilaksanakan oleh raja/ratu harus terlebih dahulu mendengar pendapat atau pertimbangan menteri. Suatu kekuasaan prerogatif yang sudah diatur dalam undang-undang tidak disebut sebagai hak prerogatif lagi, melainkan sebagai hak yang berdasarkan undang-undang. Jadi, kekuasaan prerogatif mengandung beberapa karakter; (1) sebagai residual power; (2) merupakan kekuasaan diskresi (fries ermessen, beleid); (3) tidak ada dalam hukum tertulis: (4) - penggunaan dibatasi; (5) akan hilang apabila telah diatur dalam UU atau UUD. ${ }^{8}$

Senada dengan usulan Bagir Manan. Mahfud MD. juga mengusulkan agar penggunaan hak prerogatif presiden dalam pembentukan lembaga-lembaga pemerintahan dan pengangkatan pejabat negara tertentu oleh Presiden untuk masa mendatang sebaiknya dimintakan konfirmasi kepada DPR. Hal ini dimaksudkan agar hak prerogatif tidak dimanfaatkan untuk menggalang dukungan politik atau menyingkirkan lawan politik bahkan membangun mitra kolusi dalam berbagai hal. Disamping itu, untuk mengontrol

5/bid.

${ }^{7}$ Harian Republika. 27 Mei 2000.

s/bid. 
hak prerogatif Presiden dalam bidang perundang-undangan perlu diberi jalan pelaksanaan lembaga judicial review. ${ }^{9}$

\section{Perdebatan Hak Prerogatif di Indonesia}

Sejarah ketatanegaraan Indonesia mencatat hanya satu kali terjadi konflik yang sungguh-sungguh antara Presiden dengan Badan Pekerja di Komite Nasional Indonesia Pusat (KNIP), yaitu dalam hubungan Peraturan Pemerintah No. 6 Tahun 1946 tentang penyempurnaan Susunan KNIP. Pada 16 Oktober 1945 keanggotaan KNIP telah diperbanyak menjadi 188 orang anggota. Semenjak Januari 1946, beberapa partai politik mulai mendesak supaya susunan KNIP diubah sesuai dengan apa yang disebut sebagai perimbangan yang sebenarnya dari kekuatan-kekuatan politik, berbeda dari perimbangan yang diwakili dalam KNIP.10

Pada 10 Juli 1946 Badan Pekerja KNIP yang beranggota 200 orang telah diperbarui dengan Undang-Undang No. 12 Tahun 1946. Undang-undang ini memberi kesempatan kepada Panitia Pemilihan di daerah-daerah untuk mengambil inisiatif memilih 110 anggota, kepada partai-partai politik untuk memilih 60 orang anggota lain. Hanya 30 anggota yang akan ditunjuk oleh Presiden.

Untuk pelaksanaan UU itu memerlukan persetujuan partai-partai mengenai susunan Panitia Pemilihan Daerah. Oleh karena itu, partai-partai tidak menyetujui hal ini. Disamping itu, mengenai pembagian 60 kursi,
UU itu pun tidak dapat dilaksanakan. Badan Pekerja berdebat dan mengusahakan amandemen terhadap UU itu, tetapi tidak pernah mencapai penyelesaian terakhir. Setelah itu Presiden dengan Peraturan Presiden' No. 6 Tahun 1946 menetapkan penambahan anggota KNIP dari 200 menjadi 514 orang.

Pada 6 Januari 1947 dalam sidang pertama Badan Pekerja di Solo setelah keluarnya Peraturan Presiden No. 6. Tahun 1946, anggota-anggota Badan Pekerja telah mengemukakan keberatan-keberatan yang prinsipiil terhadap tindakan Presiden. Berlainan dengan kebiasaan yang terjadi setelah dijalankannya sistem Kabinet yang bertanggungjawab, dimana segala UU dan Peraturan Pemerintah disamping memuat tanda tangan Presiden memuat pula tanda tangan Menteri yang bertanggungjawab. Peraturan Pemerintah No. 6 Tahun 1946 hanya ditandatangani oleh Presiden dengan tiada ikut sertanya tanda tangan Menteri yang bertanggungjawab. Presiden menyatakan kepada Badan Pekerja, beliau sendirilah yang bertanggungjawab terhadap. Peraturan Presiden. Kabinet dalam pernyataannya pada 17 Januari 1947 berkeyakinan bahwa pengeluaran peraturan yang seperti itu adalah termasuk prerogatif Presiden. Sebagian besar anggota Badan Pekerja berpendapat bahwa meskipun Presiden boleh mengambil inisiatif untuk mengeluarkan peraturan yang serupa itu, tetapi peraturan itu tidak dapat berlaku, sebagai halnya peraturan biasa, sampai disetujui Badan Pekerja.",

9Moh. Mahfud MD. 1999. Hukum dan Pilar-pilar Demokrasi. Yogyakarta: Gama Media.Hilm.. 269-270. ${ }^{10}$ Ismail Suny. HIm.. 58.

$11 /$ bid. HIm.. 47. 
Selama tidak ada suatu undang-undang yang mengatur penunjukan anggota KNIP, Presiden menganggap soal itu sebagai prerogatifnya, karena itu, pengaturannya dalam Peraturan Pemerintah. Oleh karena dengan penarikan rencana undang-undang dari Badan Pekerja tidak terdapat suatu sikap resmi dan positif dari KNIP terhadap persoalan itu, dapatlah disimpulkan bahwa KNIP mengakui prerogatif Presiden untuk menunjuk anggota-anggota KNIP sampai ada suatu UU yang mengatur soal tersebut.

UUD, menurut A.K. Pringgodigdo, memberikan hak prerogatif pada Presiden khususnya dalam pembentukan kabinet: ${ }^{12}$

"...betul jika hal pembentukan kabinet dipandang sebagai prerogatif Presiden; dalam hal inilah sebetulnya ia ikut bertanggungjawab. Maka dari itu pula pasal-pasal dalam UUD yang menyatakan bahwa salah sesuatu dilakukan oleh Presiden, tidak memberi kepadanya sesuatu prerogatif, akan tetapi hanya menjamin bahwa hal itu akan diatur atau diputus oleh Kabinet atau Menteri yang bersangkutan dan aturan atau putusan itu akan ditandatangani oleh Presiden (dengan contraseign Menteri). Jadi untuk tempo dahulu (diwaktu raja masih mempunyai prerogatif-prerogatif yang dijamin dalam UUD) hal-hal yang demikian itu merupakan "prerogatieven van de Kroon", pada waktu sekarang pasal-pasal itu hanya menjamin bahwa hal-hal itu akan diurus di tingkat lebih tinggi dari tingkat Menteri sendiri."
Menurut Konstitusi RIS (UUD 1949) dan UUD Sementara 1950 hak prerogatif Presiden misalnya ditetapkan dalam membentuk kementerian-kementerian (Pasal 50 UUDS 1950); berhak membubarkan DPR (Pasal 84 UUDS 1950); memberikan tanda-tanda kehormatan (Pasal 126 KRIS 1949. Pasal 87 UUDS 1950); memberi grasi (Pasal 160 KRIS 1949, Pasal 107 UUDS 1950); mengadakan traktat dengan negara-negara lain (Pasal 175 KRIS 1949, Pasal 120 UUDS 1950); mengangkat wakil-wakil RI pada negaranegara lain (Pasal 178 KRIS 1950, Pasal 123 UUDS 1950); menerima wakil-wakil negaranegara lain pada RI (Pasal 178 KRIS 1949, Pasal 123 UUDS 1950); menyatakan perang (Pasal 128 UUDS 1950); menyatakan keadaan bahaya (Pasal 129 UUDS 1950).

UUD 1945 memberikan kedudukan yang kuat kepada lembaga kepresidenan. Presiden adalah penyelenggara pemerintahan (Pasal 4 ayat (1)). Selain kekuasaan eksekutif, Presiden juga menjalankan kekuasaan membentuk peraturan perundang-undangan (Pasal 5 dan Pasal 22), kekuasaan yang berkaitan dengan penegakan hukum, seperti memberi grasi, amnesti, dan abolisi (Pasal 14). Dalam menjalankan kekuasaannya Presiden dibantu oleh satu orang Wakil Presiden (Pasal 4 ayat (2)) dan sejumlah menteri (Pasal 17). Di akhir masa jabatannya, Presiden bertanggungjawab kepada MPR. Hal ini didasarkan pada pemikiran bahwa Presiden adalah mandataris Majelis. Dengan kata lain, dalam hubungan dengan MPR. kedudukan Presiden lebih ditekankan sebagai

${ }^{2}$ A.K. Pringgodigdo. 1956. Kedudukan Presiden Menurut Tiga Undang-Undang Dasar dalam Teori dan Praktek. Jakarta: PT Pembangunan. Hlm. 30-31. 
mandataris. Sebagai konsekuensi, di satu pihak MPR dianggap berwenang memberikan berbagai mandat di luar yang telah ditentukan UUD 1945 seperti "pelimpahan wewenang khusus", ${ }^{3}$ dan di lain pihak, Presiden terutama dinilai sebagai mandataris yaitu pelaksana mandat MPR. ${ }^{14}$

Batang tubuh UUD 1945 tidak memuat pranata mandatäris. Demikian pula Presiden sebagai kepala negara dan kepala pemerintahan. Dua pengertian terakhir ini menurut Bagir Manan, sebetulnya merupakan pengertian yang bersifat analisis keilmuan dan hanya tampak pada sistem parlementer. Pada sistem presidensiil, tidak ada Presiden sebagai kepala negara dan kepala pemerintahan. Begitu pula mengenai sebutan "mandataris". Tidak ada maksud Soepomo yang menyusun penjelasan untuk memberi kualitas dan kualifikasi tersendiri "mandataris" kepada Presiden, melainkan sekedar sebutan.15

Lebih lanjut, Bagir Manan menyatakan, dalam tugas-tugas penyelenggaràan pemerintahan yang bersifat khusus, ${ }^{16}$ tugas dan wewenang tersebut bersifat "prerogatif", tetapi ada dalam lingkungan kekuasaan pemerintahan, sehingga menjadi bagian dari objek administrasi negara.

Kekuasaan Presiden yang dirumuskan dálam Pasal 10, 11, 12, 13, 14, dan Pasal 15 UUD 1945, biasanya dipahami dalam kerangka tugas Presiden sebagai Kepala Negara, bukan sebagai Kepala Pemerintahan. Namun, karena sistem yang dianut dalam UUD 1945 bukan sistem kabinet (parlementer), maka memang tidak ditegaskan bahwa kekuasaan tersebut dikaitkan dengan fungsi Presiden sebagai Kepala Negara. Dalam sistem presidensiil yang dianut oleh UUD 1945, fungsi kepala negara dan kepala pemerintahan menyatu dalam jabatan Presiden. Tetapi secara teoritis semua kekuasaan yang disebut di atas melekat dalam fungsi Presiden RI menurut Pasal 10 sampai dengan Pasal 15 UUD 1945 adalah kekuasaan Presiden sebagai Kepala Negara, dan bukan sebagai Kepala Pemerintahan. ${ }^{17}$ Dalam hal pengangkatan pejabat setingkat menteri, sepenuhnya merupakan hak prerogatif Presiden sebaagai Mandataris MPR. ${ }^{18}$ Hanya pada pengangkatan pimpinan lemibaga-lembaga tinggi negara HIm. $4 \dot{5}$.

'Terakhir diatur dalam TAP MPR No. VMPR/1998 dan telah dicabut dengan TAP MPR No. XIIMPR/ 1998 hasil Sidang Istimewa MPR:

:Bagir Manan. 1999. Lembaga Kepresidenan. Yogyakarta: Pusat Studi Hukum Fakultas Hukum Ull.

${ }^{15} /$ bid. HIm. 46.

:6Yang dimaksud dengan tugas-tugas penyelenggaraan pemerintahan yang bersifat khusus adalah penyelenggaraan tugas dan wewenang pemerintahan yang secara konstitusional ada pada Presiden pribadi yang memiliki sifat prerogatif (di bidang pemerintahan). Tugas dan wewenang pemerintahan tersebut adalah: Presıden sebagai pimpinan tertinggi angkatan perang, hubungan luar negeri, dan hak memberi gelar dan tanda jasa (Pasal 10, 11, 13, dan Pasal 15 UUD 1945).

${ }^{77} \mathrm{Jimly}$ Asshiddiqie. 1996. Pergumulan Peran Pemerintah dan Parlemen dalam Sejarah. Jakarta: UI Press. HIm. 78.

t8/bid. Hlm. 8. 
lainnya. yaitu pengangkatan Ketua MA, Ketua DPA, Ketua BPK, DPR dapat berperan.

Model Amerika Serikat sebagai pencerminan stelsel sistem pemerintahan presidensiil (murni) antara lain memiliki ciriciri: Presiden adalah pemegang kekuasaan eksekutif tunggal (Pasal 2 ayat (91) angka 1 UUD Amerika Serikat); Presiden adalah penyelenggara pemerintahan yang bertanggungjawab di samping berbagai wewenang konstitusional yang bersifat prerogatif yang lazim melekat pada jabatan kepala negara (head of state)..$^{19}$

Dalam kedudukan sebagai Kepala Negara, menurut Solly Lubis, ${ }^{20}$ Presiden mempunyai hak-hak prerogatif, selain menyangkut kewenang ke dalam juga kewenangan dalam hubungan ke luar, yang dalam UUD 1945 diperinci dari Pasal 10 sampai dengan Pasal 15. Sebagaimana disebut dalam penjelasan Pasal 10 sampai dengan Pasal 15, kekuasaan-kekuasaan Presiden dalam pasal-pasal itu ialah konsekuensi dari kedudukan Presiden sebagai Kepala Negara. Dari sudut sistem nasional, kaitan yang penting antara kewenangan prerogatif dengan kepemimpinan nasional ialah kecenderungan orientatif yang perlu dikembangkan pada sikap dan kebijakan Kepala Negara dalam melaksanakan tugas-tugas dan kewenangan prerogatif itu, sehingga konsisten selalu dengan nilai-nilai, asas-asas dan normanorma yang terdapat dalam ketiga landasan ketatanegaraan kita.

Dalam kaitan ini, S. Toto Pandoyo: menyatakan, seorang kepala negara, baik seorang raja maupun Presiden, tentu memiliki hak prerogatif atau ada yang menyebutnya dengan istilah hak khusus atau hak.istimewa. Bagi negara-negara hukum demokratik, tentunya ketentuan dan macam serta jumlah hak prerogatif dimaksud tercantum tegastegas di dalam konstitusi negara yang bersangkutan. Hal ini dimaksudkan untuk menjaga jangan sampai hak-hak prerogatif yang dimaksud lama kelamaan menjadi bertambah jumlah. dan macamnya. Selain itu. untuk menjaga hak-hak tersebut termasuk hak prerogatif, agar lama-kelamaan tidak berkembang isi dan maknanya, maka diperlukan adanya penjelasan yang lengkap.

Menurut Moh. Mahfud MD., pemberian hak prerogatif untuk melakukan hal-hal tertentu bagi Presiden merupakan konsekuensi dari minimal dua hal: kertama, penganutan paham negara hukum material (welfare state), dan kedua, penunjukan Presiden sebagai mandataris MPR. ${ }^{22}$

Pertama, di dalam wawasan negara hukum material ini fungsi dan tugas pemerintah direntang menjadi sedemikıan luas sehingga tidak lagi sekedar melaksanakan UU melainkan melakukan

${ }^{19}$ Bagir Manan. Lembaga ... Op.Cit. Hlm. 50.

${ }^{20}$ Solly Lubis dalam Padmo Wahjono (editor). 1984. Masalah Ketatanegaraan Indonesia Dewasa Ini. Jakarta: Ghalia Indonesia. HIm. 197-198.

2:S. Toto Pandoyo, daiam Hikmat Hardono dan R. Yunita (editor). 1997. Tidak Tak terbatas Kajian atas Lembaga Kepresidenan RI. Yogyakarta: Pandega Media bekerjasama dengan Badan Eksekutif Mahasıswa UGM. HIm. 72.

${ }^{22}$ Moh. Mahfud MD. Op.Cit. HIm. 257. 
berbagai hal menurut kreasi dan kewenangannya sendiri. Tugas pokok pemerintah di dalam negara hukum material ini adalah membangun kesejahteraan masyarakat, bukan hanya melaksanakan UU. Untuk itu diciptakanlah lembaga kewenangan yang disebut freies ermessen, yaitu suatu kewenangan bagi pemerintah untuk turut campur atau melakukan intervensi di dalam berbagai kegiatan masyarakat guna membangun kesejahteraan masyarakat tersebut. Dengan demikian, pemerintah di dalam negara hukum material ini dituntut untuk bersikap aktif.

Freies ermessen bagi pemerintah di negara hukum material menimbulkan implikasi baik di bidang eksekutif maupun di bidang perundang-undangan. Dalam bidang perundang-undangan dapat dicatat adanya tiga macam kewenangan bagi pemerintah yaitu kewenangan inisiatif (membuat peraturan yang sederajat dengan UU tanpa harus minta persetujuan parlemen lebih dahulu dengan syarat bahwa peraturan tersebut dibuat karena keadaan memaksa); kewenangan delegasi (membuat peraturan pelaksanaan atas ketentuan-ketentuan UU); dan droit function (membuat penafsiran sendiri atas materi peraturan). Dalam bidang pemerintahan implikasi freies ermessen ini, antara lain, ditandai dengan adanya hak prerogatif., ${ }^{23}$

Dengan demikian, seberapa besar porsi untuk memegang hak prerogatif bagi pemerintah akan sangat ditentukan oleh seberapa besar pula penganutan terhadap wawasan negara hukum. Artinya, di dalam negara yang cenderung menganut faham negara hukum material, porsi hak prerogatifnya akan lebih besar daripada negara yang cenderung pada wawasan negara hukum formal.

Pada umumnya hak prerogatif diberikan juga kepada Kepala Negara dalam bidang yudikatif terutama dalam hal peniadaan atau pengurangan hukuman dalam apa yang yang disebut grasi. Hak yang seperti itu tidaklah semata-mata dikaitkan dengan wawasan negara kesejahteraan, tetapi dikaitkan dengan kepentingan politik negara pada umumnya.

Kedua, menurut prinsip konstitusi. kedaulatan di Indonesia terletak pada rakyat yang pada operasionalnya dilakukan MPR. Berdasarkan prinsip tersebut, maka MPR, atas nama rakyat membuat garis-garis kebajikan negara (national policies) yang untuk pelaksanaannya dimandatkan kepada Presiden. Untuk melaksanakan mandat tersebut Presiden mendapatkan hak-hak istimewa dalam masalah-masalah tertentu yang disebut hak prerogatif. Dengan hak prerogatif inj Presiden diberi kewenangan sepenuhnya untuk menentukan sendiri masalah-masalah tertentu yang berkaitan dengan pelaksanaan tugasnya tanpa harus konsultasi dengan lembaga negara lainnya.

Sebagai penganut wawasan negara hukum material dan penentu bahwa Presiden adalah mandataris pemegang kedaulatan, maka Indonesia melalui UUD 1945 telah memberikan hak prerogatif mengenai soalsoal tertentu kepada Presiden. Hak prerogatif Presiden itu meliputi hal-hal:: ${ }^{24}$

\footnotetext{
23/bid. HIm. 258.

${ }^{24} \mathrm{~b}$ bid. Hllm. 263-264.
} 
1. Dalam bidang pemerintahan

a. Menyatakan keadaan bahaya yang syarat-syarat dan akibatnya ditetapkan lebih dahulu) dengan UU (Pasal.12).

b. Mengangkat duta dan konsul (Pasal 13 ayat (1)).

c. Memberi gelar, tanda jasa, dan tanda kehormatan (Pasal 15).

d. Mengangkat dan memberhentikan menteri (Pasal 17 ayat (2)). .

2. Dalam bidang perundang-undangan

a. Menetapkan Peraturan Pẹmerintah untuk menjalankan UU sebagaimana mestinya (Pasal 5 ayat (2)).

b. Menetapkan Perpu jika negara dalam keadaan genting (Pasal 22 ayat (1)).

3. Dalam bidang peradilan

Memberi grasi, amnesti, abolisi, dan rehabilitasi (Pasal 14). Perlu juga ditambahkan bahwa hak-hak prerogatif di atas adalah hakhak yang secara langsung dicantumkan di dalam UUD 1945. Di luar UUD 1945 (misalnya melalui TAP MPR atau UU) masih terdapat hak-hak prerogatif lainnya seperti pengangkatan gubernur, kepala lembaga pemerintahan non departemen, pembuatan Keppres, Inpres dan sebagainya.

Menurut. Mahfud MD., ada atau tidak hak prerogatif dalam konstitusi tidak menjadi masalah, tergantung bagaimana memaknai hak prerogatif itu. Sebab hak prerogatif itu ada jika Presiden berhak melakukan sesuatu tanpa meminta persetujuan orang atau lembaga lain.
Oleh karena itu, hak prerogatif tidak perlu dihapus, melainkan dikurangi. ${ }^{25}$ Tetapi, Bagir Manan maupun Samsul Wahidin mengatakan, bahwa pengangkatan dan pemberhentian menteri bukan merupakan hak prerogatif Presiden. Lebih lanjut Bagir Manan mengatakan: ${ }^{26}$

"Dalam UUD 1945, kekuasaan yang serupa dengan kekuasaan prerogatif diatur antara Pasal 10 sampai dengan Pasal 15. Wewenang Presiden yang lazim disebut hak prerogatif tersebut bersumber dan diciptakan secara hukum oleh dan dalam UUD 1945. Kekuasaan tersebut bukan sekedar terdapat, tetapi sebagai sesuatu yang diciptakan oleh UUD 1945. Kekuasaan ini, ditinjau dari pengertian hukum (rechtsbegrip), tidak mengandung karakter residu, tidak mengandung karakter diskresi, melainkan kekuasaan yang lingkup dan jenisnya lahir dan ditentukan oleh hukum.

Karenà diatur dalam UUD, maka bersifat dan merupakan kekuasaan konstitusional (constitutional power). Jadi, sistem ketatanegaraan Indonesia tidak mengenal kekuasaan prerogatif. Yang ada adalah kekuasaan konstitusional yang dalam berbagai hal serupa dengan kekuasaan prerogatif."

Demikian pula pandangan Samsul Wahidin, ${ }^{27}$ yang mengatakan bahwa masalah kementerian negara bukan kewenangan Presiden dalam kedudukannya sebagai

${ }^{25}$ Harian Republika. Mei 2000.

${ }^{26}$ Harian Republika. 27 Mei 2000.

${ }^{27}$ Samsul Wahidin. "Menguji Hak Prerogatif Presiden."Harian Jawa Pos. Senin. 1 Mei 2000. 
kepala negara. Menteri negara adalah pembantu Presiden di lapangan pemerintahan dan dalam kapasitas Presiden sebagai kepala pemerintahan.

Dengan dasar argumentasi berbeda, Padmo Wahjono, ${ }^{28}$ berpendapat bahwa UUD 1945 tidak mengenal hak prerogatif. la mengingatkan, Penjelasan Pasal 10 sampai dengan Pasal 15 menyebutkan bahwa kekuasaan Presiden di dalam pasal-pasal tersebut adalah konsekuensi dari kedudukan Presiden sebagai Kepala Negara. Ragam kekuasaan itu lazim disebut sebagai kekuasaan atau kegiatan yang bersifat administratif karena didasarkan dari peraturan perundang-undangan ataupun pertimbangan dari lembaga tinggi negara lainnya. Jadi, bukan kewenangan khusus (hak prerogatif) yang mandiri.

\section{Hak Prerogatif Setelah Perubahan UUD 1945}

Dalam sistem UUD 1945 seperti dijelaskan oleh Supomo, memang direka sedemikian rupa sehingga kekuasan terpusat pada Presiden (concentration of power and responsibility upon the President) atau menurut ungkapan yang popular: executive heavy. Bahkan, dalam sidang Dokuritzu Zyunbi Chosa Kai, Soepomo berkata:

“...buat (penyelenggaraan pemerintahan) sehari-hari Presidenlah yang: merupakan penjelmaan kedaulatan rakyat".
“... yang merupakan penjelmaan kedaulatan rakyat ialah Presiden, bukan Dewan Perwakilan rakyat".

Begitu pula penegasan yang ada di dalam Pasal 4 ayat (1) UUD 1945, mengatakan Presiden Republik Indonesia memegang kekuasaan pemerintahan menurut UUD. Jadi, fungsi eksekutif diserahkan kepada Presiden. ${ }^{2:}$

Secara tegas Harun Alrasid tidak mengatakan bahwa Presiden dalam.kerangka UUD 1945 memiliki hak prerogatif, tetapi dari uraiannya dapat diketahui bahwa Presiden memiliki hak prerogatif. Misalnya, Presiden memegang kekuasaan yang tertinggi atas Angkatan Darat, Angkatan Laut, dan Angkatan Udara, sehingga keputusan tingkat puncak dalam bidang militer berada di tangan Presiden.

Presiden, berwenang menyatakan keadaan bahaya. Hal ini berarti bahwa dalam hal seluruh atau sebagian wilayah negara akan dinyatakan dalam keadaan darurat sipil. keadaan darurat militer, atau keadaan perang, sepenuhnya merupakan wewenang Presiden tanpa persetujuan jabatan lain.

Presiden, juga tanpa persetujuan jabatan lain, berwenang untuk mengangkat menteri. Ketentuan menteri diangkat dan diberhentikan oleh Presiden, dikaitkan dengan ketentuan bahwa kekuasaan pemerintahan dipegang oleh presiden, maka ditarik kesimpulan bahwa berlaku sistem pemerintahan presidensial.

${ }^{28}$ Forum Keadilan. Loc. Cit.

¿Harun Alrasid. "Jabatan Presiden RI Sebuah Tinjauan Hukum Tata Negara." Pidato Dies Rede pada Sidang Senat Terbuka Dalam Rangka Dies Natalis Ull Yogyakarta. 8 November 1999. HIm. 15. 
Selanjutnya, dalam hal ikhwal kegentingan memaksa, Presiden berwenang mengeluarkan peraturan yang derajatnya sama dengan UU (noodverordeningsrecht), yaitu peraturan pemerintah pengganti undangundang (Perpu). Dengan menggunakan kewenangan itu, Presiden secara sepihak dapat mencabut UU yang masih berlaku atau mengatur sesuatu hal yang seharusnya ditetapkan dengan UU.

Tidak hanya mengenai pengeluaran Perpu yang sifatnya darurat, bahkan dalam hal negara berada dalam keadaan darurat, Presiden juga memegang peranan penting karena dapat menggunakan apa yang dalam teori hukum tata negara disebut dengan istilah "hak darurat negara" (staatsnoodrecht). Berdasarkan kewenangan yang tidak tertulis ini, kalau Presiden menganggap bahwa negara berada dalam keadaan darurat maka untuk mengatasinya dia dapat mengambil keputusan yang melanggar peraturan yang berlaku, bahkan ketentuan UUD sekalipun..$^{30}$

Pasal 4 ayat (1) di atas menegaskan pada masa Orde Baru dianggap sebagai sumber kewenangan dan dipergunakan sebagai dasar hukum dari berbagai Keputusan Presiden. Penggunaan Pasal 4 ayat (1) sebagai sumber wewenang itu, dipelopori oleh Hamid Attamimi, yang mengatakan: ${ }^{31}$

"Apabila kekuasaan pengaturan oleh presiden dengan persetujuan DPR yang lahir dari Pasal 5 ayat (1) UUD 1945 mewujudkan undang-undang, dan yang lahir dari Pasal 5 ayat (2) mewujudkan Peraturan pemerintah, maka wujud apakah yang lahir dari kekuasaan pengaturan oleh Presiden berdasarkan Pasal 4 ayat (1) UUD 1945? Mengenai hal ini terdapat beberapa pendapat. baik yang dating dari pada teoritisi maupun dari para praktisi..."

Alhasil, selama sama jabatannya yang lima tahun itu, Presiden dapat melaksanakan segala kekuasaan (kewenangan) yang dipusatkan padanya. Walau de jure Presiden adalah untergeordnet pada MPR, namun mengingat kedudukannya sebagai Kepala Negara dan Kepala Pemerintahan, maka Presiden adalah pejabat terpenting dalam tata negara Indonesia.

Belakangan ini muncul aspirasi politik yang menghendaki supaya dipakai sistem perimbangan kekuasaan (checks and balances). Dalam sidang umum MPR 1 sampai dengan 21 Oktober 1999, gagasan mengenai perimbangan kekuasaan mendapat respons. Pada 19 Oktober 1999 diterima Perubahan Pertama UUD 1945. Ada sembilan Pasal yang diubah, yaitu: Pasal 5. 7, 9. 13, 14, 15, 17. 20. 21.

Dalam kaitannya dengan wewenang Presiden baik yang tunggal ataupun yang memerlukan kerjasama dengan pihak lain. ternyata mengalami pengurangan (pembatasan) yang cukup besar. Hasil Perubahan Pertama UUD 1945 Pasal 5, yang tadinya Presiden "memegang kekuasaan" membentuk UU, sekarang diubah, Presiden

30/bid. HIm. 18-20.

${ }^{31}$ A. Hamid S. Attamimi. "Peranan Keputusan Presiden RI dalam Penyelenggaraan Pemerintahan Negara." Disertasi. Universitas Indonesia. Jakarta. 1990. HIm. 182-183. 
tidak lagi memegang kekuasaan membentuk UU, tetapi "berhak mengajukan" Rancangan Undang-Undang (RUU).

Masa jabatan Presiden dan Wakil Presiden, sekarang sudah ada penegasannya di dalam UUD 1945. Apabila sebelumnya dalam Pasal 7 tidak ada pembatasan masa jabatan bagi seorang Presiden dan Wakil Presiden, sehingga dapat ditafsirkan selamanya dapat berkuasa asalkan masih terus dipilih dan mendapat dukungan mayoritas anggota MPR, seperti jaman Orde Baru, setelah diubah berbunyi: "Presiden dan Wakil Presiden memegang jabatannya selama lima tahun dan sesudahnya dapat dipilih kembali dạlam jabatan yang sama, hanya untuk satu kali masa jabatan."

Demikian pula ketentuan Pasal 13, dalam hal kewenangan Presiden untuk mengangkat duta dan konsul, serta menerima duta negara lain, juga mengalami pembatasan. Kewenangan Presiden dalam persoalan ini tadinya bersifat tunggal, artinya Presiden tidak perlu minta persetujuan pihak lain, sekarang, untuk pelaksanaannya Presiden ("harus") memperhatikan pertimbangan DPR. Jadi, tidak lagi merupakan prerogatif Presiden. Nampak aspek perimbangan kekuasaan mengenai hubungan Presiden dan DPR muncul dalam persoalan ini.

Kewenangan Presiden untuk memberi grasi, amnesti, abolisi dan rehabilitasi, sebagaimana yang diatur dalam Pasal 14, juga mengalami pembatasan. Sekarang, dalam hal Presiden memberi grasi dan rehabilitasi, ("harus") memperhatikan pertimbangan Mahlamah Agung. Apabila Presiden memberi amnesti dan abolisi, juga ("harus") memperhatikan pertimbangan DPR. Di sini nampak aspek perimbangan kekuasaan tidak hanya antara Presiden dengan DPR tetapi juga dengan MA.

Demikian pula kewenangan Presiden dalam memberi gelaran, tanda jasa, dan lainlain tanda kehormatan, sebagaimana diatur dalam Pasal 15, juga mengalami pengurangan. Presiden tidak lagi sepenuhnya memiliki prerogatif, karena kewenangan Presiden untuk memberi gelar; tanda jasa, dan lain-lain tanda kehormatan akan diatur dengan UU. Artinya, ada alat ukur atau kriteria yang jelas dalam penerapannya. Pengalaman selama ini dalam hal pemberian gelar, tanda jasa dan lain-lain tanda kehormatan hanya digantungkan pada penilaian "loyalitas" subjektif Presiden. Perubahan ini mengisyaratkan secara implisit harus ada persetujuan DPR.

Pembahasan berikutnya tentang Kementerian Negara, yang diatur dalam Pasal 17 UUD 1945. Ternyata perubahan yang dilakukan terhadap pasal ini tidak terlalu besar dampaknya bagi kekuasaan Presiden, seperti pasal-pasal. lainnya, karena hanya merubah redaksional ayat (2) dan (3), sehingga berbunyi: ·

(2) Menteri-menteri itu diangkat dan diberhentikan oleh Presiden.

(3) Setiap menteri membidangi urusan tertentu dalam pemerintahan.

Padahal banyak masukan dari masyarakat agar dalam pengangkatan ataupun pemberhentian menteri DPR dilibatkan. Penglibatan DPR dalam masalah ini dapat dalam hal penyusunan UU atau adanya persetujuan DPR secara langsung. Hai ini penting dilakukan agar Presiden lebih cermat dan berhati-hati dalam mengangkat ataupun memberhentikan seseorang. Artinya, ada 
kriteria yang jelas dan tegas dalam pengangkatan maupun pemberhentian menteri. Kasus pemberhentian Yusuf Kalla dan Laksamana Sukardi yang telah dibahas di atas, adalan contoh aktual untuk persoalan ini. UUD 1945 memang tidak secara tegas mengatur masalah ini, tetapi praktek politik menunjukkan bahwa dalam hal pengangkatan dan pemberhentian menteri Presiden "harus mendapat persetujuan" dari DPR. Apalagi kalau naiknya seseorang dalam jabatan Presiden berdasarkan dukungan (koàlisi) sejumlah partai-partai politik, etika politik menghendaki adanya konfirmasi dengan mereka, jika Presiden hendak mengangkat ataupun memberhentikan menterimenterinya.

Dalam Sidang Tahunan MPR Ṙ November 2001; MPR telah menghasilkan Perubahan Ketiga UUD 1945. Salah satu hasil perubahannya adalah menambah satu ayat untuk Pasal 17 sehingga menjadi empat ayat. Pasal 17 ayat (4) berbunyi: "Pembentukan, pengubahan, 'dan pembubaran kementerian negara diatur dalam undang-undang".

Latar belakang penambahan ayat (4) tersebut antara lain besarnyá wewenang Presiden dalam persoalan ini. Misalnya, kètika Jaman pemerintàhàn Soeharto (Orde Baru). jumlah dan macamnya kementerian negara sangat ditentukan oleh "kebutuhan dan kepentingan politiknya". Demikian pula pada masa pemerintahan Abdurrahman Wahid, jumlah dan macamnya kementerian negara ditentukan oleh kepentingan politik dari partaipartai politik dan militer yang ada di DPR saat itu. Bahkan, di era Presiden Abdurraham Wahid beberapa kementerian (departemen) dihapus. Akibat dari kebijakan tersebut, sampai sekarang penataan ulangnya dari departemen-departemen tersebut belum juga dapat diselesaikan.

Bagaimana dengan kewenangan Presiden yang lain, misalnya, Pasal 10,11 , dan 12 UUD 1945 yang selama ini juga dipandang sebagai wewenang prerogatif Presiden?

Meskipun Pasal 10 tidak (belum) diubah oleh MPR sebagaimana pasal-pasal yang lain, tetapi melalui Sidang Tahunan MPR 7 sampai dengan 18 Agustus 2000 telah lahir antara lain Ketetapan MPR No. VI /MPR/2000 tentang Pemisahan TNI dan Kepolisian Negäa RI, dan Ketetapan MPR No. VII/MPR/2000 tentang Peran TNI dan Kepolisian Negara RI. Melalui Ketetapan MPR No. VII/MPR/2000 susunan dan kedudukan TNI ditegaskan bahwa TNI dipimpin oleh seorang Panglima yang diangkat dan diberhentikan oleh Presiden setelah mendapat persetujuan DPR (Pasal 3 ayat (3)). Demikian pula susunan dan kedudukan Kepolisian Negara RI, ditegaskan bahwa Kepolisian Negara RI dipimpin oleh Kepala Kepolisiän Negara RI yang diangkat dan diberhentikan oleh Presiden dengan persetujuan DPR (Pasal 7 ayat (3)). Penegàsan di dalam Pasal 3 ayat (3) mäupun Pasal 7 ayat (3) TAP MPR No. VII/MPR/2000 secara substantif telah membatasi kewenangan Presiden yang diatur dalam Pasal 10 UUD 1945. Dengan kata lain, Presiden tidak lagi sepenuhnya memiliki hak prerogatif dalam hal pengangkatan dan pemberhentian Panglima TNI maupun Kapolri karena adanya keharusan persetujuan DPR.

Sebagaimana yang telah disinggung di atas, ketika Presiden Abdurrahman Wahid menonaktifkan kemudian memberhentikan Jenderal Polisi Surojo Bimantoro dari jabatannya sebagai Kapolri, Adnan Buyung Nasution dkk, -yang bertindak sebagai kuasa 
hukum dari Persatuan Purnawirawan POLRLmengajukan permohonan keberatan melalui Hak Uji Materiil MA atas keputusan Presiden tersebut. Melalui permohonan keberatan Hak Uji Materiil tersebut, Buyung Nasution mendalilkan bahwa penerbitan Keputuśan Presiden (Keppres) No. 49 Tahun 2001 tentang Pencabutan Penonaktifan,.dan Pemberhentian Dengan Hormat Jenderal Polisi Drs. Surojo Bimantoro dari jabatannya sebagai Kapolri tidak didahului dengan adanya persetujuan DPR sebagaimana ditentukan dalam Pasal 7 ayat (3) Ketetapan MPR RI No. VII/MPR/2000, jelas dan nyata bahwa Keppres tersebut telah menjadi bentuk kooptasi oleh Presiden terhadap POLRI. Persyaratan untuk memberhentikan Kapolri harus dengan persetujuan DPR tersebut menunjukkan dan membuktikan bahwa Kapolri merupakan jabatan publik mengingat di dalam jabatan Kapolri -yang merupakan .pemegang komando secara riil/langsung terhadap institusi POLRI - terkandung kewenangan yang akan membawa dampak atau akibat terhadap kehidupan berbangsa, bernegara dan bermasyarakat. ${ }^{32}$

Dalam Pasal 11 UUD 1945 diatur kewenangan Presiden dengan persetujuan DPR menyatakan perang, membuat perdamaian dan perjanjian dengan negara lain. Ketentuan tersebut melalui sidang tahunan MPR RI Tahun 2001 telah diubah (Perubahan Ketiga) dan ditambah sebagai berikut:

(2) Presiden dalam membuat perjanjian internasional lainnya yang menimbulkan akibat yang luas dan mendasar bagi kehidupan rakyat yang terkait dengan beban keuangan negara, dan/atau mengharuskan perubahan atau pembentukan undang-undang harus dengan persetujuan DPR.

(3) Ketentuan lebih lanjut tentang perjanjian internasional diatur dengan undang-undang.

Perubahan dan penambahan dalam Pasal 11 ini merupakan penegasan atas ketidakjelasan praktek selama ini, khususnya dalam pembuatan perjanjian dengan negara lain. Perjanjian mana yang harus dengan persetujuan DPR dan mana yang tidak perlu dengan persetujuan DPR, tidak ada ketegasan. Semuanya seolah bergantung pada political will Pemerintah (Presiden). Selama ini aturan pelaksana Pasal 11 hanya diatur dalam Surat Presiden No. 2826/HK/ 1960, yang jelas sudah tidak cocok lagi untuk diterapkan saat ini, karena situasi dan kondisinya sudah berbeda. Oleh karena itu. baru pada 2000 Pemerintah mengeluarkan UU No. 24 Tahun 2000 tentang Perjanjian Internasional.

Pasal 12 UUD 1945 sampai saat ini tidak (belum) diubah. Pembuat UUD 1945

32Lihat Putusan Perkara Permohonan Keberatan Hak Uji Materïl Mahkamah Agung No. 08 P/HUM/2001. 24 Juli 2001. 
memandang arti penting dan bahaya dari suatu keadaan yang dinyatakan bahaya. Oleh karena itu, ada pembatasan wewenang kepada Presiden tentang kapan Presiden dibenarkan menyatakan keadaan bahaya. Sekaligus ditetapkan perubahan ketatanegaraan sebagai akibat pernyataan keadaan bahaya. ${ }^{33}$ Namun, sampai saat ini, UU yang mengatur lebih lanjut mengenai syarat dan akibat keadaan bahaya masih aturan yang lama, yakni UU No. 23 Tahun 1959. Sementara itu, UU pengganti belum juga kunjung disahkan. Bahkan, RUU Penanggulangan Keadaan Bahaya yang telah disetujui oleh DPR menjadi UU, juga belum diundangkan oleh Presiden hingga saat ini.

Akibatnya, ketika Presiden Abdurrahman Wahid mengeluarkan Maklumat (atau lebih dikenal dengan Dekrit) menimbułkan sikap pro dan kontra di MPR dan masyarakat, karena dasar pijakan yuridis yang dipakai oleh Presiden Abdurrahman Wahid masih mengacu pada. UU No. 23/Prp/1959. Presiden berpandangan bahwa pemberlakuan keadaan darurat adalah wewenangnya tanpa perlu meminta persetujuan DPR. Tetapi Maklumat Presiden tersebut ditolak oleh anggota-anggota MPR. Dari 601' Anggota MPR yang hadir, 599 menyatakan menolak dan dua Anggota abstain. Sikap MPR terhadap Maklumat Presiden tersebut kemudian dikukuhkan dalam Ketetapan MPR RI No. I/ MPR/2001 dengan menyatakan Maklumat Presiden Republik Indonesia 23 Juli 2001 adalah tidak sạh karena bertentangan dengan hukum dan tidak mempunyai kekuatan hukum. Peristiwa ini akhirnya mengantarkan Presiden Abdurrahman Wahid turun dari kekuasaannya melalui Sidang Istimewa MPR. ${ }^{34}$

\section{Simpulan}

Secara umum dapat dipahami bahwa UUD 1945 memberikan wewenang prerogatif pada Presiden melalui Pasal 10 sampai dengan Pasal 15 dan Pasal 17, sehingga Presiden dalam melaksanakan wewenangnya tidak perlu meminta persetujuan lembaga lain. misalnya DPR. Akan tetapi, ketika UUD 1945 telah diubah sampai tiga kali, struktur UUD 1945 mengalami perubahan yang luar biasa. Pasal-pasal yang tadinya memberikan wewenang penuh kepada Presiden untuk menyelenggarakan pemerintahan, setelah terjadi perubahan (pertama, kedua dan ketiga) UUD 1945 wewenang Presiden mengalami pengurangan yang cukup besar. Ada keharusan bagi Presiden untuk meminta persetujuan dari DPR (Pasal 11 dan 15), tetapi ada jugä yang "harus" memperhatikan pertimbangan DPR (Pasal 13, Pasal 14 ayat (2), atau pertimbangan MA (Pasal 14 ayat (1)).

Dalam hal pengangkatan dan pemberhentian Panglima TNI dan Kapolri, yang selama ini dipahami sebagai wewenang penuh Presiden atas dasar Pasal 10 UUD 1945, dengan dikeluarkannya Ketetapan MPR

33Suwoto Mulyosudarmo. "UU tentang KKN dalam Perspektif Hukum Tata Negara." Dalam Ignatius Haryanto. 1999. Kejahatan Negara, Telaah tentang Penerapan Delik Keamanan Negara. Jakarta: ELSAM. HIm. X.

${ }^{34} \mathrm{Ni}$ 'matul Huda. "Kontroversi Dasar Hukum Sidang Istimewa MPR dan Maklumat Presiden 23 Juli 2001 (Tinjauan Yuridis Ketatanegaraan)." Jurnal Hukum, No. 16 Vol. 8 - 2001. HIlm. 107. 
No. VI/MPR/2000 dan Ketetapan MPR No. VII/ MPR/2000 secara substantif telah mengurangi wewenang Presiden, karena adanya keharusan bagi Presiden untuk meminta persetujuan DPR. Secara akademis persoalan ini masih diperdebatkan, berkaitan dengan kedudukan Ketetapan MPR No. VII/MPR/2000 apakah sudah operasional atau belum.

Ke depan, kekuasaan Presiden harus ada pengaturannya secara tegas di dalam konstitusi ataupun UU. agar mudah dikontrol pelaksanaannya. Untuk itu, DPR harus aktif mengawasi jalannya pemerintahan dengan menggunakan hak-haknya secara optimal dan proporsionai. 7

\section{Daftar Pustaka}

A. Hamid S. Attamimi. "Peranan Keputusan Presiden RI dalam Penyelenggaraan Pemerintahan Negara." Disertasi. Universitas Indonesia. Jakarta. 1990.

A.K. Pringgodigdo. 1956. Kedudukan Presiden Menurut Tiga UndangUndang Dasar dalam Teori dan Praktek. Jakarta: PT Pembangunan.

Bagir Manan. "UUD1945 Tak Mengenal Hak Prerogatif." Harian Republika. Sabtu. 27 Mei 2000.

-_- 1999. Lembaga Kepresidenan. Yogyakarta: Pusat Studi Hukum Fakultas Hukum UII.

Harun Alrasid. "Jabatan Presiden RI Sebuah Tinjauan Hukum Tata Negara." Pidato Dies Rede pada Sidang Senat Terbuka Dalam Rangka Dies Natalis UII Yogyakarta. 8 November 1999.
Ismail Suny. 1986. Pergeseran Kekuasaan Eksekutif. Jakarta: Aksara Baru.

Jimly Asshiddiqie. 1996. Pergumulan Peran Pemerintah dan Parlemen dalam Sejarah. Jakarta: UI Press.

Moh. Mahfud MD. 1999. Hukum dan Pilarpilar Demokrasi. Yogyakarta: Gama Media.

Ni'matul Huda. "Kontroversi Dasar Hukum Sidang Istimewa MPR dan Maklumat Presiden 23 Juli 2001 (Tinjauan Yuridis Ketatanegaraan)." Jurnal Hukum, No. 16 Vol. 8 - 2001.

Samsul Wahidin. "Menguji Hak Prerogatif Presiden."Harian Jawa Pos. Senin. 1 Mei 2000.

Solly Lubis dalam Padmo Wahjono (editor). 1984. Masalah Ketatanegaraan Indonesia Dewasa Ini. Jakarta: Ghalia Indonesia.

S. Toto Pandoyo, dalam Hikmat Hardono dan R. Yunita (editor). 1997. Tidak Tak terbatas Kajian atas Lembaga Kepresidenan RI. Yogyakarta: Pandega Media bekerjasama dengan Badan Eksekutif Mahasiswa UGM.

Suwoto Mulyosudarmo. "UU tentang KKN dalam Perspektif Hukum Tata Negara." Dalam Ignatius Haryanto. 1999. Kejahatan Negara, Telaah tentang Penerapan Delik Keamanan Negara. Jakarta: ELSAM.

Putusan Mahkamah Agung No. 08 P/HUMi 2001 tentang Putusan Menerima Keberatan atas Permohonan Hak Uji Materiil yang dimajukan oleh Tim Pembela Konstitusi 31 Juli 2001. 
Putusan Perkara Permohonan Keberatan Hak Harian Republika. 27 Mei 2000.

Uji Materiil Mahkamah Agung No. 08

P/HUM/2001. 24 Juli 2001.

Forum Keadilan. No. 19, 12 Agustus 2001. Harian Republika. 27 Mei 2000.

Harian Republika. Mej 2000. 